\title{
Germination of "Solo" papaya seeds treated with plant hormones"
}

\author{
Rafael Fonsêca Zanotti²* Denise Cunha Fernandes dos Santos Dias², \\ Raimundo Santos Barros ${ }^{3}$, Laércio Junio da Silva ${ }^{2}$, Marcelo Coelho Sekita ${ }^{2}$
}

\begin{abstract}
The aim of this study was to investigate the effects of some plant hormones on germination of Carica papaya L. seeds of the "Solo" group taken from fruits at maturity stages 3 and 5 (50\% and 75\% of the fruit skin showing a yellow color). Then, the seeds were subjected to treatments involving different combinations of acid 2-chloroethylphosphonic - (CEPA $0 ; 5$ $\mathrm{x} 10^{-7}$ and $\left.5 \times 10^{-4} \mathrm{M}\right), \mathrm{GA}_{3}(0 ; 10$ and $50 \mathrm{mg} / \mathrm{L})$ and $\mathrm{KNO}_{3}(0$ or $1 \mathrm{M})$, and germination was assessed at the 14th and 30th days. Seeds from fruits at maturity stage 3 showed increased germination when treated with all growth regulators tested. $\mathrm{KNO}_{3}$ promoted a decrease in germination and in the germination speed index, especially in the seeds from stage 5. The plant hormones did not promote any increase in percentage of normal seedlings of papaya seeds. Two-Chloethylphosphonic acid $\left(5 \times 10^{-4} \mathrm{M}\right)$ and the gibberellic acid applied alone in the seeds from satge 3 promoted an increase in the number of normal seedlings 14 days after sowing.
\end{abstract}

Index terms: Carica papaya, CEPA, AG, phytohormones, $\mathrm{KNO}_{3}$.

\section{Germinação de sementes de mamão tratadas com fitohormônios}

\begin{abstract}
RESUMO - Sementes de mamão têm germinação lenta e desuniforme o que tem sido atribuído à dormência pós-colheita. Objetivou-se com o presente trabalho avaliar os efeitos de reguladores de crescimento na germinação de sementes de mamão grupo "Solo". As sementes foram extraídas de frutos nos estádios de maturação 3 e 5, que correspondem a 50\% e mais que $75 \%$ da superfície externa amarela, respectivamente. Em seguida, foram submetidas a tratamentos constituidos por diferentes combinações de ácido 2-cloroetilfosfônico - CEPA (0; 5 x 10-7 e $\left.5 \times 10^{-4} \mathrm{M}\right), \mathrm{GA}_{3}(0 ; 10$ e $50 \mathrm{mg} / \mathrm{L})$ e $\mathrm{KNO}_{3}(0$ ou $1 \mathrm{M})$, avaliando-se a germinação aos 14 e 30 dias. Verificou-se aumento da germinação das sementes no estádio 3 de maturação quando tratadas com os reguladores de crescimento testados. $\mathrm{O} \mathrm{KNO}_{3}$ teve efeito negativo na germinação e no índice de velocidade de germinação, principalmente nas sementes do estádio 5. Não houve efeito dos reguladores de crescimento na porcentagem final de plântulas normais. $\operatorname{OCEPA}\left(5 \times 10^{-4} \mathrm{M}\right)$ e as giberelinas empregadas isoladamente promoveram aumento do número de plântulas normais das sementes no estádio 3, aos 14 dias após a semeadura.
\end{abstract}

Termos para indexação: Carica papaya, CEPA, giberelina, reguladores de crescimento, $\mathrm{KNO}_{3}$.

\section{Introduction}

Germination of papaya (Carica papaya) seeds is slow and variable (Tokuhisa et al., 2007a), which can be attributed to the action of phenolic compounds (Tokuhisa et al., 2007b). Some studies demonstrated a positive effect of plant hormones on germination of this seeds, increasing the germination speed and uniformity of papaya seeds of the "Formosa" group (Tokuhisa et al., 2007a; Lopes et al., 2009). However, studies on seeds of the "Solo" group are scarce.

Among the growth regulators that have influence on germination of papaya seeds are gibberellins (Tokuhisa et

${ }^{1}$ Submitted on 10/30/2013. Accepted for publication on 02/26/2014. ${ }^{2}$ Departamento de Fitotecnia, Universidade Federal de Viçosa, 36570-000 Viçosa, MG, Brasil. al., 2007a; Lopes et al., 2009), ethylene (Linkies et al., 2009) and $\mathrm{KNO}_{3}$ (Tokuhisa et al., 2007a; Dias et al., 2012). Gibberellins act in the mobilization of seed reserves during the germination process (Müller et al., 2006). Therefore, they are considered important germination promoters and contribute to increased seed germination speed and uniformity, thus improving the performance of papaya seeds (Tokuhisa et al., 2007a; Lopes et al., 2009). Ethylene is also considered a seed germination promoter. This hormone inhibits the action of abscisic acid and causes the weakening and rupture of the tegument (Linkies et al., 2009). To release ethylene artificially into the cells, 2-chloroethylphosphonic acid - CEPA is used (Burin et al., 1987).

${ }^{3}$ Departamento de Biologia Vegetal, Universidade Federal de Viçosa 36570-000 Viçosa, MG, Brasil.

*Corresponding author<fael_zanotti@yahoo.com.br> 
$\mathrm{KNO}_{3}$ is another major promoter of papaya seeds germination (Tokuhisa et al., 2007a; Dias et al., 2012). However, up to the present time its specific effect has not been fully understood because it can either act on biosynthesis and/or an increased sensitivity to gibberellins (Gb) (Alboresi et al., 2005).

Another fact that may impact the percentage and speed rate of papaya seeds germination is the fruit maturity stage (Lopes et al., 2009). Seeds extracted from fruits at different maturity stages present different sensitivity levels to growth regulators (Firn, 1986). However, there is little information on the relation of papaya seeds germination with the action of growth regulators and the fruit maturity stage.

Thus, the present work aimed to assess the effects of $\mathrm{CEPA}, \mathrm{GA}_{3}$ and $\mathrm{KNO}_{3}$ on the germination of "Solo" papaya seeds collected from fruits at two maturity stages, namely, stages 3 and 5 .

\section{Material and Methods}

The study was conducted in the Laboratory of Seed Analysis of the Department of Plant Science of the Federal University of Viçosa, Viçosa, MG, Brazil, using "Solo" papaya seeds. The fruits were harvested at stage 3 of maturity (semiripe, i.e., $50 \%$ of yellow skin) and stage 5 (ripe, more than $75 \%$ of yellow fruit surface skin), according to Lopes et al. (2009).

Once taken out from the fruits, the seeds were rubbed with paper sheets and washed in running water to remove the sarcotesta. Then, they were naturally dried on three sheets of paper towel and maintained in laboratory conditions until reaching moisture content of approximately $10 \%$, which occurred in approximately 10 days. The seeds water content was determined by the oven method at $105 \pm 3{ }^{\circ} \mathrm{C}$ for 24 hours, with two replications (Brasil, 2009) of 50 seeds each. The results were expressed in percentage.

After drying, the seeds were treated with plant hormones. To accomplish this, the seeds were first immersed in distilled water or in a solution of $1 \mathrm{M}$ of $\mathrm{KNO}_{3}$ for $60 \mathrm{~min}$ and then washed in running water. Subsequently, the seeds were tested for germination, which was performed in paper towel moistened with the following solutions:

- Gibberellic acid $\left(\mathrm{GA}_{3}\right)$ : in the concentration of 0 (distilled water), $10 \mathrm{mg} / \mathrm{L}\left(2.8 \times 10^{-5} \mathrm{M}\right)$ and $50 \mathrm{mg} / \mathrm{L}\left(1.4 \times 10^{-4} \mathrm{M}\right)$;

- CEPA: in the concentration of 0 (distilled water), $5 \mathrm{x}$ $10^{-7} \mathrm{M}$ and $5 \times 10^{-4} \mathrm{M}$.

The control treatment consisted of seeds immersed only in distilled water for 60 minutes and placed to germinate in paper towel moistened with distilled water.

The experimental treatments used are shown in Table 1.

Table 1. Treatments applied to "Solo" papaya seeds taken from fruits at maturity stages 3 and 5.

\begin{tabular}{lll}
\hline \multicolumn{1}{c}{ Treatment } & \multicolumn{1}{c}{ Legend } \\
\hline Distilled water & control \\
$\left(\mathrm{CEPA}(0 \mathrm{M})+\mathrm{GA}_{3}(0 \mathrm{mg} / \mathrm{L})+\mathrm{KNO}_{3}(1 \mathrm{M})\right.$ & $\mathrm{K}$ \\
$\left(\mathrm{CEPA}(0 \mathrm{M})+\mathrm{GA}_{3}(10 \mathrm{mg} / \mathrm{L})+\mathrm{KNO}_{3}(0 \mathrm{M})\right.$ & $\mathrm{G}(10)$ \\
$\left(\mathrm{CEPA}(0 \mathrm{M})+\mathrm{GA}_{3}(10 \mathrm{mg} / \mathrm{L})+\mathrm{KNO}_{3}(1 \mathrm{M})\right.$ & $\mathrm{G}(10)+\mathrm{K}$ \\
$\left(\mathrm{CEPA}(0 \mathrm{M})+\mathrm{GA}_{3}(50 \mathrm{mg} / \mathrm{L})+\mathrm{KNO}_{3}(0 \mathrm{M})\right.$ & $\mathrm{G}(50)$ \\
$\left(\mathrm{CEPA}(0 \mathrm{M})+\mathrm{GA}_{3}(50 \mathrm{mg} / \mathrm{L})+\mathrm{KNO}_{3}(1 \mathrm{M})\right.$ & $\mathrm{G}(50)+\mathrm{K}$ \\
$\left(\mathrm{CEPA}\left(5 \times 10^{-7} \mathrm{M}\right)+\mathrm{GA}_{3}(0 \mathrm{mg} / \mathrm{L})+\mathrm{KNO}_{3}(0 \mathrm{M})\right.$ & $\mathrm{C}\left(5 \times 10^{-7}\right)$ \\
$\left(\mathrm{CEPA}\left(5 \times 10^{-7} \mathrm{M}\right)+\mathrm{GA}_{3}(0 \mathrm{mg} / \mathrm{L})+\mathrm{KNO}_{3}(1 \mathrm{M})\right.$ & $\mathrm{C}\left(5 \times 10^{-7}\right)+\mathrm{K}$ \\
$\left(\mathrm{CEPA}\left(5 \times 10^{-7} \mathrm{M}\right)+\mathrm{GA}_{3}(10 \mathrm{mg} / \mathrm{L})+\mathrm{KNO}_{3}(0 \mathrm{M})\right.$ & $\mathrm{C}\left(5 \times 10^{-7}\right)+\mathrm{G}(10)$ \\
$\left(\mathrm{CEPA}\left(5 \times 10^{-7} \mathrm{M}\right)+\mathrm{GA}_{3}(10 \mathrm{mg} / \mathrm{L})+\mathrm{KNO}_{3}(1 \mathrm{M})\right.$ & $\mathrm{C}\left(5 \times 10^{-7}\right)+\mathrm{G}(10)+\mathrm{K}$ \\
$\left(\mathrm{CEPA}\left(5 \times 10^{-7} \mathrm{M}\right)+\mathrm{GA}_{3}(50 \mathrm{mg} / \mathrm{L})+\mathrm{KNO}_{3}(0 \mathrm{M})\right.$ & $\mathrm{C}\left(5 \times 10^{-7}\right)+\mathrm{G}(50)$ \\
$\left(\mathrm{CEPA}\left(5 \times 10^{-7} \mathrm{M}\right)+\mathrm{GA}_{3}(50 \mathrm{mg} / \mathrm{L})+\mathrm{KNO}_{3}(1 \mathrm{M})\right.$ & $\mathrm{C}\left(5 \times 10^{-7}\right)+\mathrm{G}(50)+\mathrm{K}$ \\
$\left(\mathrm{CEPA}\left(5 \times 10^{-4} \mathrm{M}\right)+\mathrm{GA}_{3}(0 \mathrm{mg} / \mathrm{L})+\mathrm{KNO}_{3}(0 \mathrm{M})\right.$ & $\mathrm{C}\left(5 \times 10^{-4}\right)$ \\
$\left(\mathrm{CEPA}\left(5 \times 10^{-4} \mathrm{M}\right)+\mathrm{GA}_{3}(0 \mathrm{mg} / \mathrm{L})+\mathrm{KNO}_{3}(1 \mathrm{M})\right.$ & $\mathrm{C}\left(5 \times 10^{-4}\right)+\mathrm{K}$ \\
$\left(\mathrm{CEPA}\left(5 \times 10^{-4} \mathrm{M}\right)+\mathrm{GA}_{3}(10 \mathrm{mg} / \mathrm{L})+\mathrm{KNO}_{3}(0 \mathrm{M})\right.$ & $\mathrm{C}\left(5 \times 10^{-4} 4\right)+\mathrm{G}(10)$ \\
$\left(\mathrm{CEPA}\left(5 \times 10^{-4} \mathrm{M}\right)+\mathrm{GA}_{3}(10 \mathrm{mg} / \mathrm{L})+\mathrm{KNO}_{3}(1 \mathrm{M})\right.$ & $\mathrm{C}\left(5 \times 10^{-4}\right)+\mathrm{G}(10)+\mathrm{K}$ \\
$\left(\mathrm{CEPA}\left(5 \times 10^{-4} \mathrm{M}\right)+\mathrm{GA}_{3}(50 \mathrm{mg} / \mathrm{L})+\mathrm{KNO}_{3}(0 \mathrm{M})\right.$ & $\mathrm{C}\left(5 \times 10^{-4}\right)+\mathrm{G}(50)$ \\
$\left(\mathrm{CEPA}\left(5 \times 10^{-4} \mathrm{M}\right)+\mathrm{GA}_{3}(50 \mathrm{mg} / \mathrm{L})+\mathrm{KNO}_{3}(1 \mathrm{M})\right.$ & $\mathrm{C}\left(5 \times 10^{-4}\right)+\mathrm{G}(50)+\mathrm{K}$ \\
\hline
\end{tabular}

For the germination test, four replications of 50 seeds for each maturity stage and for each treatment were placed on two sheets of paper towel moistened with a volume of solution (water for the control or CEPA $+\mathrm{GA}_{3}+\mathrm{KNO}_{3}$ ), equivalent to 2.5 times the mass of dry paper. Then, the seeds were covered with another sheet of paper towel and 
the rolls were made. The rolls were kept in a Mangelsdorfftype germinator at an alternating temperature of $20-30^{\circ} \mathrm{C}(16 / 8$ hours, night/day, respectively), according to Brasil (2009). The germination index was recorded every two days for 30 days. The seeds showing radicle protrusion were considered as germinated. It was considered normal seedlings those having the aerial part at least $2 \mathrm{~cm}$ long. The percentages of seeds that showed radicle emergence after 14 days and 30 days of sowing as well as the percentages of normal seedlings were recorded (Brasil, 2009). The data obtained every two days were used to estimate the radicle protrusion speed rate (RPSR) based on the data of emergence of the primary root, and the germination speed index (GSI) based on the data of normal seedlings, according to Maguire (1962).

The experiment was conducted on a randomized, complete-block design, with four replications. Data were subjected to the analysis of variance in a $2 \times 18$ factorial design corresponding to two maturity stages and 18 combinations of growth regulators. For purposes of analysis, the percentage data were transformed in arc-sen $\sqrt{\frac{x}{100}}$, because they had not presented normal distribution by the Kolmogorov-Smirnov test. However, in the tables the first values were expressed. The treatment averages, i.e., the different concentrations of growth regulators were compared by the Scott-Knott test. The averages relating to the maturity stages were compared by the F-test, with 5\% probability. The statistical analyses were performed using the SAS statistical package.

\section{Results and Discussion}

In the $14^{\text {th }}$ day after sowing, for maturity stage 3 , the percentage of control seeds (not treated with plant hormones) that presented radicle emergence was of $66 \%$, while the percentage of normal seedlings corresponded to $18 \%$. For stage $5,73 \%$ of the seeds showed radicle emergence and $32 \%$ of normal seedlings (Table 2).

Table 2. Percentage of seeds with radicle protrusion and normal seedlings 14 days after sowing of papaya seeds from "Solo" fruits harvested at maturity stages 3 and 5 and treated with different growth regulators.

\begin{tabular}{|c|c|c|c|c|}
\hline \multirow{2}{*}{ Treatments } & \multicolumn{2}{|c|}{ Radicle protrusion $(\%)$} & \multicolumn{2}{|c|}{ Normal seedlings $(\%)$} \\
\hline & Stage 3 & Stage 5 & Stage 3 & Stage 5 \\
\hline Control & $57 \mathrm{bA}^{*}$ & $73 \mathrm{aA}$ & $18 \mathrm{bA}$ & $32 \mathrm{aA}$ \\
\hline $\mathrm{K}$ & $75 \mathrm{aA}$ & $81 \mathrm{aA}$ & $19 \mathrm{bA}$ & $22 \mathrm{bA}$ \\
\hline $\mathrm{G}(10)$ & $49 \mathrm{cA}$ & $67 \mathrm{bA}$ & $38 \mathrm{aA}$ & $25 \mathrm{bB}$ \\
\hline$G(10)+K$ & $65 \mathrm{bA}$ & $78 \mathrm{aA}$ & $14 \mathrm{cB}$ & $23 \mathrm{bA}$ \\
\hline $\mathrm{G}(50)$ & $59 \mathrm{bA}$ & $49 \mathrm{cA}$ & $33 \mathrm{aA}$ & $26 \mathrm{bA}$ \\
\hline $\mathrm{G}(50)+\mathrm{K}$ & $78 \mathrm{aA}$ & $74 \mathrm{aA}$ & $20 \mathrm{bA}$ & $7 \mathrm{cB}$ \\
\hline $\mathrm{C}\left(5 \times 10^{-7}\right)$ & $20 \mathrm{~dB}$ & $49 \mathrm{cA}$ & $6 \mathrm{cB}$ & $14 \mathrm{cA}$ \\
\hline $\mathrm{C}\left(5 \times 10^{-7}\right)+\mathrm{K}$ & $63 \mathrm{bA}$ & $70 \mathrm{aA}$ & $7 \mathrm{cA}$ & $2 \mathrm{cA}$ \\
\hline $\mathrm{C}\left(5 \times 10^{-7}\right)+\mathrm{G}(10)$ & $20 \mathrm{~dB}$ & $48 \mathrm{cA}$ & $7 \mathrm{cA}$ & $9 \mathrm{cA}$ \\
\hline $\mathrm{C}\left(5 \times 10^{-7}\right)+\mathrm{G}(10)+\mathrm{K}$ & $63 \mathrm{bA}$ & $74 \mathrm{aA}$ & $7 \mathrm{cA}$ & $3 \mathrm{cA}$ \\
\hline $\mathrm{C}\left(5 \times 10^{-7}\right)+\mathrm{G}(50)$ & $74 \mathrm{aA}$ & $27 \mathrm{dA}$ & $3 \mathrm{cA}$ & $8 \mathrm{cA}$ \\
\hline $\mathrm{C}\left(5 \times 10^{-7}\right)+\mathrm{G}(50)+\mathrm{K}$ & $74 \mathrm{aA}$ & $73 \mathrm{aA}$ & $5 \mathrm{cA}$ & $7 \mathrm{cA}$ \\
\hline $\mathrm{C}\left(5 \times 10^{-4}\right)$ & $48 \mathrm{cA}$ & $32 \mathrm{~dB}$ & $24 \mathrm{bA}$ & $14 \mathrm{cB}$ \\
\hline $\mathrm{C}\left(5 \times 10^{-4}\right)+\mathrm{K}$ & $79 \mathrm{aA}$ & $80 \mathrm{aA}$ & $31 \mathrm{aA}$ & $7 \mathrm{cB}$ \\
\hline $\mathrm{C}\left(5 \times 10^{-4}\right)+\mathrm{G}(10)$ & $60 \mathrm{bA}$ & $56 \mathrm{bA}$ & $23 \mathrm{bA}$ & $28 \mathrm{aA}$ \\
\hline $\mathrm{C}\left(5 \times 10^{-4}\right)+\mathrm{G}(10)+\mathrm{K}$ & $80 \mathrm{aA}$ & $82 \mathrm{aA}$ & $34 \mathrm{aA}$ & $30 \mathrm{aA}$ \\
\hline $\mathrm{C}\left(5 \times 10^{-4}\right)+\mathrm{G}(50)$ & $60 \mathrm{bA}$ & $61 \mathrm{bA}$ & $28 \mathrm{aA}$ & $25 \mathrm{bA}$ \\
\hline $\mathrm{C}\left(5 \times 10^{-4}\right)+\mathrm{G}(50)+\mathrm{K}$ & $84 \mathrm{aA}$ & $83 \mathrm{aA}$ & $35 \mathrm{aA}$ & $2 \mathrm{cB}$ \\
\hline $\mathrm{CV}(\%)$ & \multicolumn{2}{|c|}{13.8} & \multicolumn{2}{|c|}{35.6} \\
\hline
\end{tabular}

*Means followed by the same lowercase letters in the column do not differ by the Scott-Knott test $(\mathrm{p}<0.05)$. Means followed by the same uppercase letter in the rows (among the maturity stages) do not differ by the F-test $(\mathrm{p}<0.05) . n=4$.

Papaya seeds of from maturity stage 3, 14 days after sowing, presented an increase of $15 \%$ points in the percentage of normal seedlings, compared to the control seeds, when treated with CEPA $5 \times 10^{-4} \mathrm{M}$ plus $\mathrm{KNO}_{3}$. The seeds of maturity stage 5 were not affected by CEPA when treated simultaneously with $\mathrm{KNO}_{3}$. But without $\mathrm{KNO}_{3}$ there was a reduction of germination of up to 25 percent points compared to the control seeds (Table 2).

The seeds of maturity stage 3 treated with CEPA $\left(5 \times 10^{-4}\right.$ $\mathrm{M})$ and $\mathrm{GA}_{3}$ showed a significant increase in the percentage 
of normal seedlings when compared to the control seeds, 14 days after sowing (Table 2). The role of these regulators (ethylene and gibberellin) in seeds germination is associated with the weakening of the tissues that cover the embryo, such as endosperm, aleurone layer and testa (Linkies et al., 2009). So, it can be inferred that the effect of these regulators allowed an increased germination of the papaya seeds.

The treatments with CEPA in a concentration $5 \times 10^{-7} \mathrm{M}$ caused a negative effect on the production of normal seedlings 14 days after sowing for the seeds of both maturity stages. It was found a decrease from $18 \%$ to $5 \%$ for the stage 3 seeds and from $32 \%$ to $7 \%$ for the stage 5 seeds, when compared to the control seeds (Table 2). Different effects of ethylene in seeds germination are found in literature, and this plant hormone, in conjunction with GA or cytokinin, caused a decrease in the germination rate of sweet passion fruit (Zucareli et al., 2003); ethylene did not affect the germination of red rice seeds, associated or not with inhibitors (2-aminoethoxyvinylglycine and silver thiosulfate) (Gianinetti et al., 2007); and it proved to be key in overcoming dormancy of Stylosanthes humilis (Ribeiro and Barros, 2006).

There was no difference in the percentage of seeds with radicle protrusion and in the percentage of normal seedlings, measured 30 days after sowing, between the seeds of both maturity stages and those that did not receive treatment. They corresponded to $71 \%$ and $81 \%$ for the seeds of stages 3 and 5 , respectively. The percentage of normal seedlings was $71 \%$ and $75 \%$ for the seeds of stages 3 and 5 , respectively (Table 3 ).

Table 3. Percentage of seeds with radicle protrusion and normal seedlings 14 days after sowing of papaya seeds from "Solo" fruits harvested at maturity stages 3 and 5 and treated with different growth regulators.

\begin{tabular}{|c|c|c|c|c|}
\hline \multirow{2}{*}{ Treatments } & \multicolumn{2}{|c|}{ Radicle protrusion (\%) } & \multicolumn{2}{|c|}{ Normal seedlings $(\%)$} \\
\hline & Stage 3 & Stage 5 & Stage 3 & Stage 5 \\
\hline Control & $71 \mathrm{bA}^{*}$ & $81 \mathrm{aA}$ & $71 \mathrm{aA}$ & $75 \mathrm{aA}$ \\
\hline $\mathrm{K}$ & $81 \mathrm{aA}$ & $86 \mathrm{aA}$ & $37 \mathrm{cB}$ & $54 \mathrm{bA}$ \\
\hline $\mathrm{G}(10)$ & $71 \mathrm{bB}$ & $88 \mathrm{aA}$ & $64 \mathrm{bB}$ & $85 \mathrm{aA}$ \\
\hline $\mathrm{G}(10)+\mathrm{K}$ & $81 \mathrm{aA}$ & $78 \mathrm{bA}$ & $38 \mathrm{cA}$ & $48 \mathrm{cA}$ \\
\hline $\mathrm{G}(50)$ & $84 \mathrm{aA}$ & $91 \mathrm{aA}$ & $78 \mathrm{aA}$ & $77 \mathrm{aA}$ \\
\hline $\mathrm{G}(50)+\mathrm{K}$ & $81 \mathrm{aA}$ & $75 \mathrm{bA}$ & $30 \mathrm{dA}$ & $11 \mathrm{eB}$ \\
\hline $\mathrm{C}\left(5 \times 10^{-7}\right)$ & $76 \mathrm{bA}$ & $82 \mathrm{aA}$ & $47 \mathrm{cA}$ & $67 \mathrm{bA}$ \\
\hline $\mathrm{C}\left(5 \times 10^{-7}\right)+\mathrm{K}$ & $81 \mathrm{aA}$ & $85 \mathrm{aA}$ & $35 \mathrm{cA}$ & $37 \mathrm{cA}$ \\
\hline $\mathrm{C}\left(5 \times 10^{-7}\right)+\mathrm{G}(10)$ & $71 \mathrm{bB}$ & $89 \mathrm{aA}$ & $46 \mathrm{cB}$ & $73 \mathrm{aA}$ \\
\hline $\mathrm{C}\left(5 \times 10^{-7}\right)+\mathrm{G}(10)+\mathrm{K}$ & $78 \mathrm{bA}$ & $82 \mathrm{aA}$ & $55 \mathrm{bA}$ & $19 \mathrm{eB}$ \\
\hline $\mathrm{C}\left(5 \times 10^{-7}\right)+\mathrm{G}(50)$ & $86 \mathrm{aA}$ & $84 \mathrm{aA}$ & $63 \mathrm{bA}$ & $66 \mathrm{bA}$ \\
\hline $\mathrm{C}\left(5 \times 10^{-7}\right)+\mathrm{G}(50)+\mathrm{K}$ & $80 \mathrm{aA}$ & $75 \mathrm{bA}$ & $34 \mathrm{cA}$ & $16 \mathrm{eB}$ \\
\hline $\mathrm{C}\left(5 \times 10^{-4}\right)$ & $69 \mathrm{bA}$ & $79 \mathrm{bA}$ & $58 \mathrm{bA}$ & $67 \mathrm{bA}$ \\
\hline $\mathrm{C}\left(5 \times 10^{-4}\right)+\mathrm{K}$ & $81 \mathrm{aA}$ & $91 \mathrm{aA}$ & $54 \mathrm{bA}$ & $26 \mathrm{~dB}$ \\
\hline $\mathrm{C}\left(5 \times 10^{-4}\right)+\mathrm{G}(10)$ & $62 \mathrm{bA}$ & $82 \mathrm{aA}$ & $73 \mathrm{aA}$ & $74 \mathrm{aA}$ \\
\hline $\mathrm{C}\left(5 \times 10^{-4}\right)+\mathrm{G}(10)+\mathrm{K}$ & $82 \mathrm{aA}$ & $83 \mathrm{aA}$ & $61 \mathrm{bA}$ & $41 \mathrm{cB}$ \\
\hline$C\left(5 \times 10^{-4}\right)+\mathrm{G}(50)$ & $74 \mathrm{bB}$ & $91 \mathrm{aA}$ & $72 \mathrm{aA}$ & $79 \mathrm{aA}$ \\
\hline $\mathrm{C}\left(5 \times 10^{-4}\right)+\mathrm{G}(50)+\mathrm{K}$ & $84 \mathrm{aA}$ & $83 \mathrm{aA}$ & $61 \mathrm{bA}$ & $28 \mathrm{~dB}$ \\
\hline CV (\%) & \multicolumn{2}{|c|}{8.7} & \multicolumn{2}{|c|}{16.1} \\
\hline
\end{tabular}

*Means followed by the same lowercase letters in the column do not differ by the Scott-Knott test $(\mathrm{p}<0.05)$. Means followed by the same uppercase letter in the rows (between maturity stages) do not differ by the F-test ( $\mathrm{p}<0.05) . n=4$.

GAs are known to increase the germination index of papaya seeds (Tokuhisa et al., 2007a). GA 3 alone, at the $14^{\text {th }}$ day after sowing, nearly doubled the number of normal seedlings for the stage 3 seeds, i.e., it increased from $18 \%$ to $38 \%$, compared to untreated seeds. On the other hand, $\mathrm{GA}_{3}$ caused a reduction of seven percentage points in the percentage of normal seedlings from stage 5 seeds compared to untreated seeds.

The stage 3 seeds presented a higher percentage of normal seedlings compared to the stage 5 seeds when treated with $\mathrm{GA}_{3}(10 \mathrm{mg} / \mathrm{L})$ (Table 2). According to Lopes et al. (2009), papaya seeds of the "Formosa" group taken from fruits at maturity stage 3 presented higher percentages of normal seedlings when treated with $\mathrm{GA}_{3}$, compared to seeds at other maturity stages. Thus, sensitivity to growth regulators is different at each seeds maturity stage, which may present a higher or lower sensitivity to the regulators used (Firn, 1986; Alberts et al., 2010).

According to Santos et al. (1999), freshly collected 
seeds from papaya of the "Solo" group presented maximum germination at maturity stage 5 . The percentage of normal seedlings from control seeds, 30 days after sowing, was nearly $73 \%$ (Table 3 ). Similar values were found by Martins et al. (2006) and Carlesso et al. (2009).

Potassium nitrate caused a significant increase of germination of the seeds of stage 3, corresponding to 18 percentage points, 14 days after sowing, and 10 percentage points 30 days after sowing, compared to the germination of untreated seeds. But, despite presenting the primary root, most of the seeds did not result in normal seedlings in the presence of $\mathrm{KNO}_{3}$. A reduction of $48 \%$ and $28 \%$ in normal seedlings was found for the seeds of stage 3 and 5 , respectively, when compared to untreated seeds (Tables 2 and 3 ).

Meireles et al. (2009) also observed a negative effect of $\mathrm{KNO}_{3}$ in germination of papaya seeds. According to this author, an increased concentration of potassium in the water during irrigation resulted in a decrease of $30 \%$ in the seed germination. In addition, Tokuhisa et al. (2007a) found reduction on percentage of germination of "Formosa" papaya seeds, which did not present dormancy, immersed in a solution of potassium nitrate for 120 minutes under a concentration of $1 \mathrm{M}$. Bhattacharya and Khuspe (2001) also observed that papaya seeds which had been previously immersed in $\mathrm{KNO}_{3} 0.1 \mathrm{M}$ for 24 hours presented a reduction in the percentage of normal seedlings. The reduced number of normal seedlings found from seeds treated with $\mathrm{KNO}_{3}$ may have been caused by water stress and/or salt stress, to which the seeds had been exposed, once the $1 \mathrm{M}$ concentration used, during 60 minutes, might have caused damages to the seeds. The decrease of the water potential may have been associated with the reduction of the oxygen availability and diffusion in the imbibition solution (Lopes and Souza, 2008).

The negative effects of $\mathrm{KNO}_{3}$ in the number of normal seedlings, 30 days after sowing, were caused by $\mathrm{GA}_{3}(50 \mathrm{mg} / \mathrm{L})$, with a reduction of $42 \%$ (stage 3 ) and $64 \%$ (stage 5) in the percentage of normal seedlings, when compared to the control seeds (Table 3).

The treatment with $\mathrm{KNO}_{3}$ resulted in an increase of the emergence speed index (ESI) of the seeds of both maturity stages. However, the germination speed index (GSI) was lower when treated with this salt. The seeds of stage 5 were more sensitive to the $\mathrm{KNO}_{3}$ solution, presenting a higher reduction in the percentage of normal seedlings. In general, the application of growth regulators in the stage 3 seeds, except for CEPA $5 \times 10^{-7} \mathrm{M}$ without $\mathrm{KNO}_{3}$, resulted in an increased ESI of the seeds (Table 4).

Table 4. Radicle protrusion speed rate (RPSR); germination speed index (GSI) of papaya seeds from "Solo" fruits harvested at maturity stages 3 and 5 and treated with different growth regulators.

\begin{tabular}{|c|c|c|c|c|}
\hline \multirow{2}{*}{ Treatments } & \multicolumn{2}{|c|}{ RPSR } & \multicolumn{2}{|c|}{ GSI } \\
\hline & Stage 3 & Stage 5 & Stage 3 & Stage 5 \\
\hline Control & $2.94 \mathrm{cA}^{*}$ & $3.6 \mathrm{bA}$ & $2.2 \mathrm{aA}$ & $2.6 \mathrm{aA}$ \\
\hline $\mathrm{K}$ & $4.33 \mathrm{aA}$ & $3.94 \mathrm{aA}$ & $1.2 \mathrm{cB}$ & $1.7 \mathrm{bA}$ \\
\hline $\mathrm{G}(10)$ & $3.09 \mathrm{bA}$ & $3.51 \mathrm{bA}$ & $2.0 \mathrm{aA}$ & $2.45 \mathrm{aA}$ \\
\hline $\mathrm{G}(10)+\mathrm{K}$ & $3.36 \mathrm{bA}$ & $3.84 \mathrm{aA}$ & $1.1 \mathrm{~dB}$ & $1.54 \mathrm{bA}$ \\
\hline $\mathrm{G}(50)$ & $3.48 \mathrm{bA}$ & $3.33 \mathrm{bA}$ & $2.36 \mathrm{aA}$ & $2.15 \mathrm{aA}$ \\
\hline $\mathrm{G}(50)+\mathrm{K}$ & $3.85 \mathrm{aA}$ & $2.74 \mathrm{cB}$ & $0.99 \mathrm{dA}$ & $0.35 \mathrm{eB}$ \\
\hline$C(5 \times 10-7)$ & $1.75 \mathrm{~dB}$ & $2.77 \mathrm{cA}$ & $1.2 \mathrm{cA}$ & $1.6 \mathrm{bA}$ \\
\hline$C(5 \times 10-7)+K$ & $3.17 \mathrm{bA}$ & $3.49 \mathrm{bA}$ & $0.94 \mathrm{dA}$ & $0.9 \mathrm{dA}$ \\
\hline$C(5 \times 10-7)+G(10)$ & $1.56 \mathrm{~dB}$ & $2.87 \mathrm{cA}$ & $0.9 \mathrm{~dB}$ & $1.6 \mathrm{bA}$ \\
\hline $\mathrm{C}(5 \times 10-7)+\mathrm{G}(10)+\mathrm{K}$ & $3.29 \mathrm{bA}$ & $3.38 \mathrm{bA}$ & $1.6 \mathrm{bA}$ & $0.5 \mathrm{eB}$ \\
\hline $\mathrm{C}(5 \times 10-7)+\mathrm{G}(50)$ & $2.31 \mathrm{cA}$ & $2.41 \mathrm{cA}$ & $1.4 \mathrm{cA}$ & $1.6 \mathrm{bA}$ \\
\hline $\mathrm{C}(5 \times 10-7)+\mathrm{G}(50)+\mathrm{K}$ & $3.51 \mathrm{bA}$ & $3.36 \mathrm{bA}$ & $1 \mathrm{dA}$ & $0.5 \mathrm{eB}$ \\
\hline $\mathrm{C}(5 \times 10-4)$ & $2.69 \mathrm{cA}$ & $2.67 \mathrm{cA}$ & $1.65 \mathrm{bA}$ & $1.6 \mathrm{bA}$ \\
\hline$C(5 \times 10-4)+K$ & $4.23 \mathrm{aA}$ & $3.72 \mathrm{aA}$ & $1.7 \mathrm{bA}$ & $0.76 \mathrm{eB}$ \\
\hline$C(5 \times 10-4)+G(10)$ & $2.87 \mathrm{cA}$ & $3.22 \mathrm{bA}$ & $1.86 \mathrm{bA}$ & $2.1 \mathrm{aA}$ \\
\hline $\mathrm{C}(5 \times 10-4)+\mathrm{G}(10)+\mathrm{K}$ & $4.15 \mathrm{aA}$ & $3.98 \mathrm{aA}$ & $2.0 \mathrm{aA}$ & $1.4 \mathrm{cB}$ \\
\hline $\mathrm{C}(5 \times 10-4)+\mathrm{G}(50)$ & $3.33 \mathrm{bA}$ & $3.55 \mathrm{bA}$ & $2.2 \mathrm{aA}$ & $2.26 \mathrm{aA}$ \\
\hline $\mathrm{C}(5 \times 10-4)+\mathrm{G}(50)+\mathrm{K}$ & $4.05 \mathrm{aA}$ & $3.68 \mathrm{bA}$ & $2.0 \mathrm{aA}$ & $0.84 \mathrm{~dB}$ \\
\hline
\end{tabular}

*Means followed by the same lowercase letters in the column do not differ by the Scott-Knott test $(p<0.05)$. Means followed by the same uppercase letter in the rows (between maturity stages) do not differ by the F-test $(\mathrm{p}<0.05) . n=4$.

Growth regulators such as $\mathrm{GA}_{3}$ and potassium nitrate were effective in increasing the germination speed and also in stimulating papaya seeds germination (Tokuhisa et al., 2007a; Lopes and Souza, 2008; Lopes et al., 2009), even with a 
reduced rate of normal seedlings (Table 4).

\section{Conclusions}

There is an increase in the germination index of the seeds of maturity stage 3 when treated with the plant hormones tested. $\mathrm{KNO}_{3}$ has a negative effect on germination and on the germination speed index, especially in the seeds of stage 5 . There is no effect of the plant hormones in the percentage of normal seedlings. CEPA $\left(5 \times 10^{-4} \mathrm{M}\right)$ and the gibberellins employed alone caused an increase in the number of normal seedlings of the seeds of stage 3,14 days after sowing.

\section{Acknowledgements}

To CNPq for the fellowship awarded to the first author and for funding the research.

\section{References}

ALBERTS, B.; JOHNSON, A.; LEWIS, J.; RAFF, M.; ROBERTS, K.; WALTER, P. Biologia molecular da célula. 5.ed. Porto Alegre: Artmed Editora, 2010. 1396 p.

ALBORESI, A.; GESTIN, C.; LEYDECKER, M-T.; BEDU, M.; MEYER, C.; TRUONG, H-N. Nitrate, a signal relieving seed dormancy in Arabidopsis. Plant Cell and Environment, v.28, n.4, p.500-512, 2005. http://www.ncbi. nlm.nih.gov/pubmed/16229082

BHATTACHARYA, J.; KHUSPE, S.S. In vitro and in vivo germination of papaya (Carica papaya L.) seeds. Scientia Horticulturae, v.91, n.1, p.39-49, 2001. http://www.sciencedirect.com/science/article/pii/S0304423801002370

BRASIL. Ministério da Agricultura, Pecuária e Abastecimento. Regras para análise de sementes. Ministério da Agricultura, Pecuária e Abastecimento. Secretaria de Defesa Agropecuária. Brasília: MAPA/ACS.2009. 395p. http:// www.bs.cca.ufsc.br/publicacoes/regras\%20analise\%20sementes.pdf

BURIN, M.E.; BARROS, R.S.; RENA, A.B. Chemical regulation of endogenous dormancy in seed of Stylosanthes humilis H.B.K. Turrialba, v.37, p.281-285, 1987.

CARLESSO, V.O.; BERBERT, P.A.; SILVA, R.F.; THIÉBAUT, J.T.L.; OLIVEIRA, M.T.R. Germinação e vigor de sementes de mamão (Carica papaya L.) cv. Golden secadas em altas temperaturas. Revista Brasileira de Sementes, v.31, n.2, 228-235, 2009. http://www.scielo.br/pdf/rbs/v31n2/v31n2a27.pdf

DIAS, M. A.; SOUZA NETO, J. D.; CONCEIÇÃO, P. M.; TOREZANI, S. C. Resposta fisiológica de sementes de mamão submetidas ao condicionamento osmótico. Revista Caatinga, v. 25, n. 4, p. 82-87, 2012. http://200.137.6.4/ revistas/index.php/sistema/article/view/2389

FIRN, R.D. Growth substance sensitivity: the need for clearer ideas, precise terms and purposeful experiments. Physiologia Plantarum, v.67, n.2, p.267-272, 1986.

GIANINETTI, A.; LAARHOVEN, L.J.J.; PERSIJN, S.T.; HARREN, F.J.M.; PETRUZZELLI, L. Ethylene production is associated with germination but not seed dormancy in red rice. Annals of Botany, v.99, n. 4, p.735-745, 2007. http://aob.oxfordjournals.org/content/99/4/735.full.pdf + html
LINKIES, A.; MÜLLER, K.; MORRIS, K.; TUREC`KOVA’, V.; CADMAN C.S.C.; CORBINEA, U.F.; STRNAD, M.; LYNN, J.R.; FINCH-SAVAGE, W.E.; LEUBNER-METZGER, G. Ethylene interacts with abscisic acid to regulate endosperm rupture during germination: a comparative approach using Lepidium sativum and Arabidopsis thaliana. The Plant Cell, v.21, n.12, p.3803-3822, 2009. http://www.dbbe.fcen.uba.ar/new/contenido/objetos/ endospermagerminacion.pdf

LOPES, H.M.; SOUZA, C.M. Efeitos da giberelina e da secagem no condicionamento osmótico sobre a viabilidade e o vigor de sementes de mamão (Carica papaya L.). Revista Brasileira de Sementes, v.30, n.1, p.181189, 2008. http://www.scielo.br/pdf/rbs/v30n1/a23v30n1.pdf

LOPES, A.W.P.; SELEGUINI, A.; BOLIANI, A.C.; CÔRREA, L.S. Estádio de maturação do fruto e uso do ácido giberélico na germinação de sementes de mamoeiro. Pesquisa Agropecuária Tropical, v.39, n.4, p.278-284, 2009. http://www.revistas.ufg.br/index.php/pat/article/view/5763

MAGUIRE, J.D. Speed of germination - aid seedling emergence and vigor. Crop Science, v.2, n.2, p.176-177, 1962.

MARTINS, G.N.; SILVA, R.F.; PEREIRA, M.G.; ARAÚJO, E.F.; POSSE, S.C.P. Influência do repouso pós-colheita de frutos na qualidade fisiológica de sementes de mamão. Revista Brasileira de Semente, v.28, n.2, p.142-146, 2006. http://www.scielo.br/pdf/rbs/v28n2/a19v28n2.pdf

MEIRELES, R.C.; SILVA, R.F.; ARAÚJO, E.F.; REIS, L.S.; LYRA, G.B.; MARINHO, A. Influência do nitrogênio e das lâminas de irrigação na qualidade fisiológica das sementes de mamoeiro. Revista Brasileira de Sementes, v.31, n.1, p.216-221, 2009. http://www.scielo.br/pdf/rbs/v31n1/a24v31n1.pdf

MÜLLER, K.; TINTELNOT, S.; LEUBNER-METZGER, G. Endospermlimited Brassicaceae seed germination: abscisic acid inhibits embryo-induced endosperm weakening of Lepidium sativum (cress) and endosperm rupture of cress and Arabidopsis thaliana. Plant Cell Physiology, v.47, n.7 p.864-877, 2006. http://pcp.oxfordjournals.org/content/47/7/864.full.pdf + html

RIBEIRO, D.M.; BARROS, R.S. Sensitivity to ethylene as a major component in the germination of seeds of Stylosanthes humilis. Seed Science Research, v.16, n.1, p.37-45, 2006. http://journals.cambridge.org/ action $/$ displayAbstract? fromPage $=$ online $\&$ aid $=705764$

SANTOS, R.C.A.; SAMPAIO, L.S.V.; COSTA, J.A. Condição ambiental, teor de água e embalagem na viabilidade e no vigor de sementes de mamão. Revista Brasileira de Sementes, v.21, n.2, p.194-202, 1999. http://www. abrates.org.br/revista/artigos/1999/v21n2/artigo30.pdf

TOKUHISA, D.; DIAS, D.C.F.S.; ALVARENGA, E.M.; DIAS, L.A.S.; MARIN, S.L.D. Tratamentos para superação da dormência em sementes de mamão. Revista Brasileira de Sementes, v.29, n.1, p.131-139, 2007a. http:// www.scielo.br/pdf/rbs/v29n1/18.pdf

TOKUHISA, D.; DIAS, D.C.F.S.; ALVARENGA, E.M.; HILST, P.C.; DEMUNER, A.J. Compostos fenólicos inibidores da germinação em sementes de mamão (Carica papaya L.). Revista Brasileira de Sementes, v.29, n.3, p.180-188, 2007b. http://www.scielo.br/pdf/rbs/v29n3/a22v29n3.pdf

ZUCARELI, C.; CASTRO, M.M.; OLIVEIRA, H.R.; BRANCALIÃO, S.R.; RODRIGUES, J.D.; ONO, E.O.; BOARO, C.S.F. Fitorreguladores e germinação de sementes de maracujá doce em condições de laboratório. Scientia Agrária, v.4, n.1-2, p.9-14, 2003. http://dialnet.unirioja.es/servlet/ articulo? codigo $=2910474$ 